\title{
Optical and Sensing Properties of Cu Doped ZnO Nanocrystalline Thin Films
}

\author{
R. K. Shukla, ${ }^{1}$ Anchal Srivastava, ${ }^{1}$ Nishant Kumar, ${ }^{1}$ Akhilesh Pandey, ${ }^{2}$ and Mamta Pandey \\ ${ }^{1}$ Department of Physics, University of Lucknow, Lucknow 226007, India \\ ${ }^{2}$ Solid State Physics Laboratory (SSPL), DRDO, New Delhi 110054, India \\ Correspondence should be addressed to Anchal Srivastava; asrivastava.lu@gmail.com
}

Received 22 July 2015; Accepted 29 September 2015

Academic Editor: Wen Zeng

Copyright (c) 2015 R. K. Shukla et al. This is an open access article distributed under the Creative Commons Attribution License, which permits unrestricted use, distribution, and reproduction in any medium, provided the original work is properly cited.

\begin{abstract}
Undoped and $\mathrm{Cu}$ doped $\mathrm{ZnO}$ films of two different molarities deposited by spray pyrolysis using zinc nitrate and cupric chloride as precursors show polycrystalline nature and hexagonal wurtzite structure of $\mathrm{ZnO}$. The crystallite size varies between 10 and $21 \mathrm{~nm}$. Doping increases the transmittance of the films whereas the optical band gap of $\mathrm{ZnO}$ is reduced from 3.28 to $3.18 \mathrm{eV}$. With increment in doping the surface morphology changes from irregular shaped grains to netted structure with holes and then to net making needle-like structures which lends gas sensing characteristics to the films. Undoped $\mathrm{ZnO}$ shows maximum sensitivity at $400^{\circ} \mathrm{C}$ for higher concentration of $\mathrm{CO}_{2}$. The sensitivity of $\mathrm{Cu}$ doped sample is maximum at $200^{\circ} \mathrm{C}$ for all $\mathrm{CO}_{2}$ concentrations from 500 to $4000 \mathrm{ppm}$.
\end{abstract}

\section{Introduction}

Zinc oxide, an environmentally safe and economic material, with wide direct band gap $(3.37 \mathrm{eV})$ and large exciton binding energy $(60 \mathrm{meV})$ at room temperature [1-3] finds application in fabrication of various devices including ultraviolet (UV) light-emitters, varistors, transparent high power electronics, piezoelectric transducers, gas sensors, smart windows, and solar cells [4-6]. It is one of the most important II-VI compound semiconductors and its application in optoelectronics can be expanded by altering its band gap energy. Doping of any metal can alter the band gap and/or can introduce energy levels in the band gap of semiconductor materials $[7,8]$. Some metals can assume a valency depending on their chemical surrounding, for example, any copper salt when doped in $\mathrm{ZnO}$ using organometallic solution can lead to varied oxidation states of $\mathrm{Cu}$ [9]. The film based gas sensors depending on the detection of variation in some electrical parameter, resistance or capacitance, of the film utilize n-type semiconducting metal oxides such as $\mathrm{ZnO}$. Also, metal oxides are stable at elevated temperatures in air [10].

There are several methods for producing $\mathrm{ZnO}$ based films, for example, chemical vapor deposition, thermal evaporation, magnetron sputtering, pulsed laser deposition (PLD), laser chemical vapor deposition, and nonvacuum methods, namely, successive ionic layer absorption and reaction (SILAR), sol-gel spin coating, spray pyrolysis, screen printing, and so forth $[1,7,11-18]$. Wet chemical techniques offer easy way for homogeneous doping of virtually any element in any proportion by merely adding it in some form of cationic solution. Moreover, these techniques do not require high quality targets and/or substrates which are unavoidable in sputtering and PLD. SILAR does not involve high temperatures allowing employment of polymers as substrates. Besides, sol-gel spin coating is a time saving process; however, it is difficult to precisely control the thickness of the films. In spray pyrolysis, oxides can be readily obtained by thermal decomposition of organometallic precursor solution during its spraying on adequately heated substrate responsible for good quality films. Thickness of the film as well as the deposition rate can be controlled over a wide range by changing the spray parameters. Also large area deposition can be done using this method. Local overheating leading to degradation of film does not occur here which is generally a matter of concern in radio frequency magnetron sputtering due to involvement of high power sources [19]. 


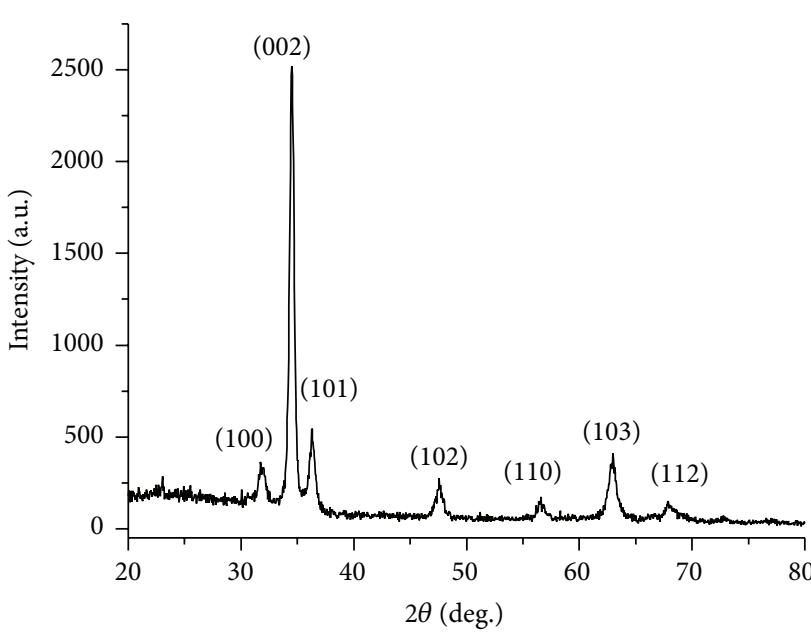

(a)

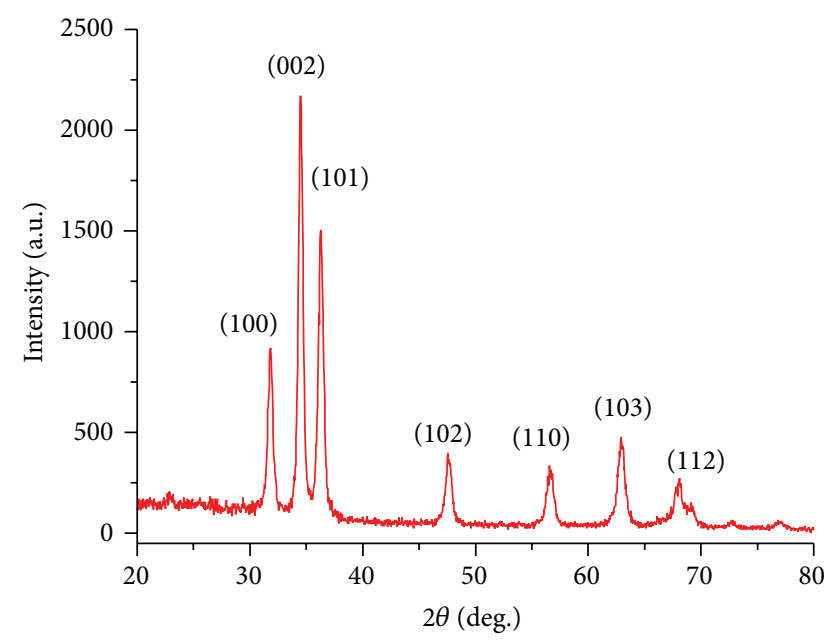

(b)

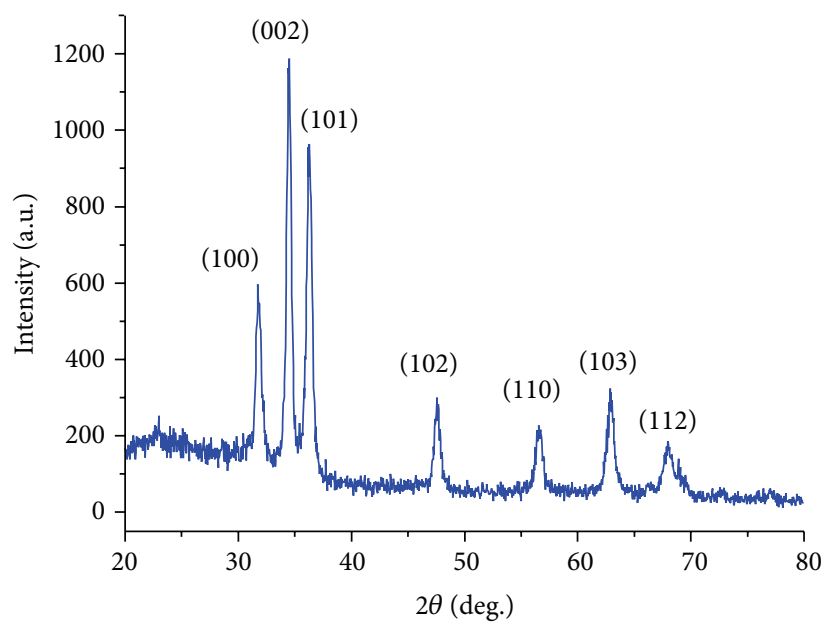

(c)

FIGURE 1: XRD pattern of undoped and $\mathrm{Cu}$ doped $\mathrm{ZnO}$ thin films sample. Here (a), (b), and (c) correspond to samples $\mathrm{Z1}$, Z1C1, and Z1C2, respectively, prepared using precursor solution of molarity of $0.1 \mathrm{M}$.

In this paper, structural, optical, and morphological property of undoped and $\mathrm{Cu}$ doped $\mathrm{ZnO}$ thin films prepared by spray pyrolysis along with $\mathrm{CO}_{2}$ sensing [20] has been presented.

\section{Experimental}

The precursor for undoped films is prepared by obtaining 0.1 and $0.15 \mathrm{M}$ solutions of zinc nitrate $(99.9 \%$ pure, S D Fine Chem. Ltd.) in deionized water. The mixture is magnetically stirred at $60^{\circ} \mathrm{C}$ for $30 \mathrm{~min}$ to get homogeneous solution. To this solution, appropriate volumes of 0.1 and $0.15 \mathrm{M}$ solutions of cupric chloride in deionized water are added to obtain 1 and 2 at.\% doping of $\mathrm{Cu}$. These solutions are again stirred for $30 \mathrm{~min}$. Both the undoped and doped solutions are aged for 15 days for obtaining stability.

The experimental set-up contains glass atomizer for spraying the precursor solution. The substrates are kept on hot iron plate which is attached with thermocouple and temperature controller to maintain the required temperature. The precursor solution is introduced in the container connected to the liquid inlet of the atomizer by a tube having solution flow controller and the compressed air used as carrier gas is let into the gas inlet of the atomizer [17].

For deposition of thin film, $10 \mathrm{~mL}$ of the precursor solution of each sample, one at a time, is transferred to the container. The distance between nozzle and the substrate is set at $25 \mathrm{~cm}$ and the flow rate is set at at $10 \mathrm{~mL} / \mathrm{min}$. The substrate temperature was maintained at $400^{\circ} \mathrm{C}$ to obtain good quality films in addition to thermal decomposition of zinc nitrate. Reactions occurring during deposition are as follows:

$$
\begin{aligned}
& \mathrm{Zn}\left(\mathrm{NO}_{3}\right)_{2} \cdot 6 \mathrm{H}_{2} \mathrm{O}+\mathrm{H}_{2} \mathrm{O} \longrightarrow \mathrm{Zn}(\mathrm{OH})_{2}+2 \mathrm{NO}_{2} \uparrow+7 \mathrm{H}_{2} \mathrm{O} \uparrow \\
& \mathrm{Zn}(\mathrm{OH})_{2} \longrightarrow \mathrm{ZnO}+\mathrm{H}_{2} \mathrm{O} \uparrow
\end{aligned}
$$

Postdeposition annealing of the films is done at $400^{\circ} \mathrm{C}$ for 30 minutes. These six samples, undoped $\mathrm{ZnO}, \mathrm{ZnO}: 1$ at. $\%$ 


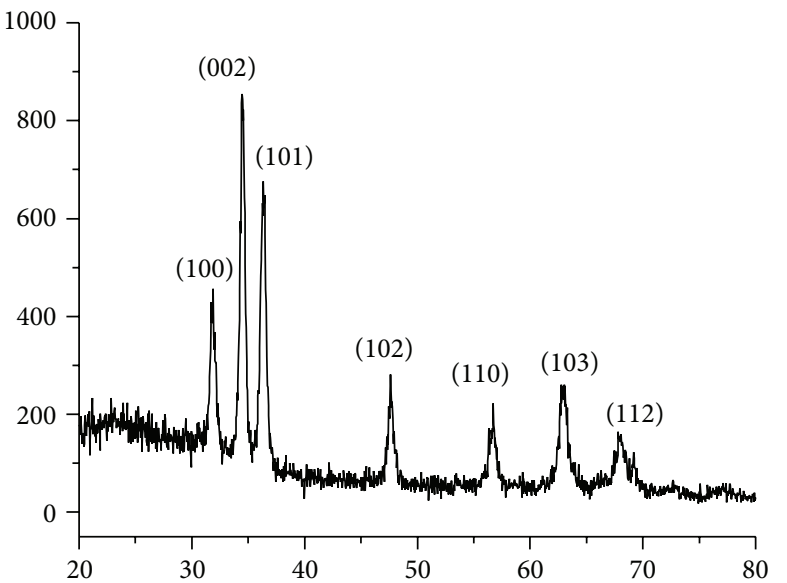

(a)

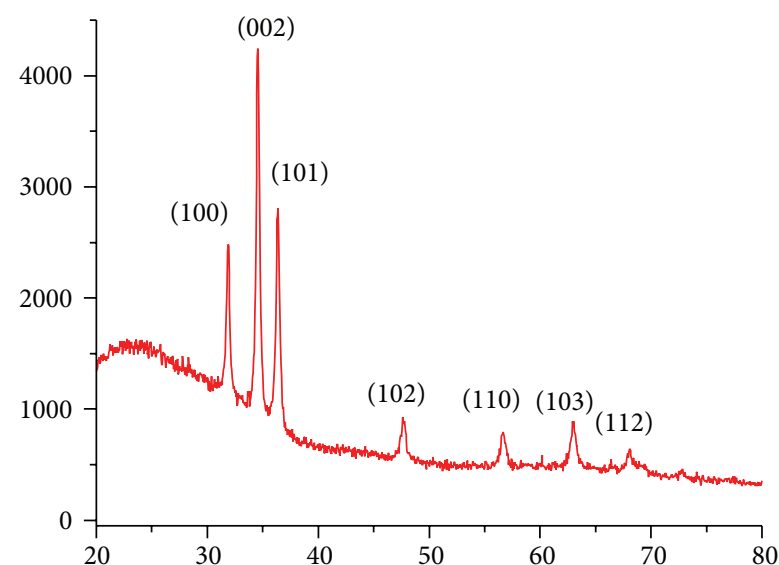

(b)

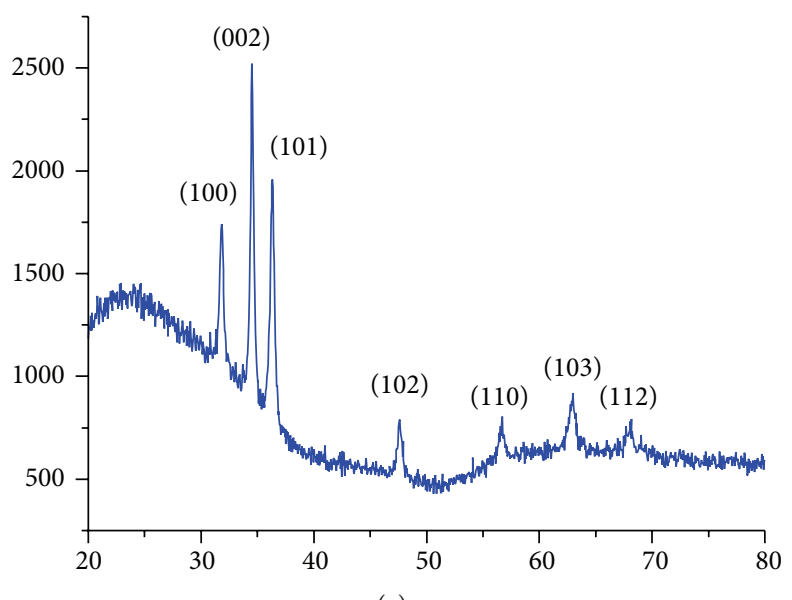

(c)

Figure 2: XRD pattern of undoped and $\mathrm{Cu}$ doped $\mathrm{ZnO}$ thin films sample. Here (a), (b), and (c) correspond to samples Z2, Z2C1, and Z2C2, respectively, prepared using precursor solution of molarity of $0.15 \mathrm{M}$.

$\mathrm{Cu}$ and $\mathrm{ZnO}: 2$ at.\% $\mathrm{Cu}$ using $0.1 \mathrm{M}$ and $0.15 \mathrm{M}$ precursor solutions, are named as $\mathrm{Z} 1, \mathrm{Z1C1}$, and $\mathrm{Z1C} 2$ and $\mathrm{Z} 2, \mathrm{Z} 2 \mathrm{Cl}$, and $\mathrm{Z} 2 \mathrm{C} 2$, respectively. Deposition parameters have been strictly kept the same to obtain films of approximately similar thickness.

The crystal phase and crystallinity of the samples have been investigated using X-ray diffractometer (Bruker D8 Advance $\mathrm{X}$-ray diffractometer) for $2 \theta$ values ranging from 20 to $80^{\circ}$ using $\mathrm{CuK} \alpha$ radiation $(\lambda=0.154 \mathrm{~nm})$. Transmittance spectra have been recorded using UV-Vis spectrophotometer (model number 108 Make-Systronics). Surface morphology is obtained using FESEM (ZEISS) and film thickness is determined by XP-1 stylus profiler (Ambios Technology).

\section{Characterization}

3.1. X-Ray Diffraction. The X-ray diffraction patterns for samples Z1, Z1C1, and Z1C2 are shown in Figure 1 and for samples Z2, Z2C1, and Z2C2 are shown in Figure 2. All the samples exhibit hexagonal wurtzite structure of $\mathrm{ZnO}$ showing preferred orientations along (100), (002), and (101)
$[1,15,21-23]$. The peak along $c$-axis, that is, (002) plane, occurs at $2 \theta=34.50,34.54^{\circ}$, and $34.47^{\circ}$ for samples $\mathrm{Z1}, \mathrm{Z1C1}$, and $\mathrm{Z1C2}$, respectively. The diffraction peak shifts to higher value for $\mathrm{Z1Cl}$ and back to lower value of $2 \theta$ for sample $\mathrm{Z1C} 2$. This indicates that initially $\mathrm{Cu}$ substitutes $\mathrm{Zn}$ and with increasing concentration of $\mathrm{Cu}$ it goes into interstitial position. For samples $\mathrm{Z} 2, \mathrm{Z} 2 \mathrm{C} 1$, and $\mathrm{Z} 2 \mathrm{C} 2,2 \theta=34.46^{\circ}$, $34.50^{\circ}$, and $34.50^{\circ}$, respectively. The diffraction peak shifts to higher value as dopant is introduced and remains unaffected thereafter. Diffraction peak except those for $\mathrm{ZnO}$ is not found for any of the samples, indicating absence of any impurity phase. Crystallite size along (002) crystallographic plane for these samples, as calculated by Debye Scherer formula, lies between 10 and $21 \mathrm{~nm}$, Table 1 . The orientation parameter $\gamma_{(h k l)}=\left(I_{(h k l)} / \sum\left(I_{(h k l)}\right)\right)[1]$, Table 1, varies from 0.127 to 0.772 indicating dominant orientation along (002) plane.

3.2. UV-Visible Spectra and Optical Band Gap. The transmittance spectra of samples prepared using precursor solutions of molarities $0.1 \mathrm{M}$ and $0.15 \mathrm{M}$ are shown in Figures 3 and 4 , respectively. The transmittance of samples $\mathrm{Z1}, \mathrm{Z1C1}$, and 


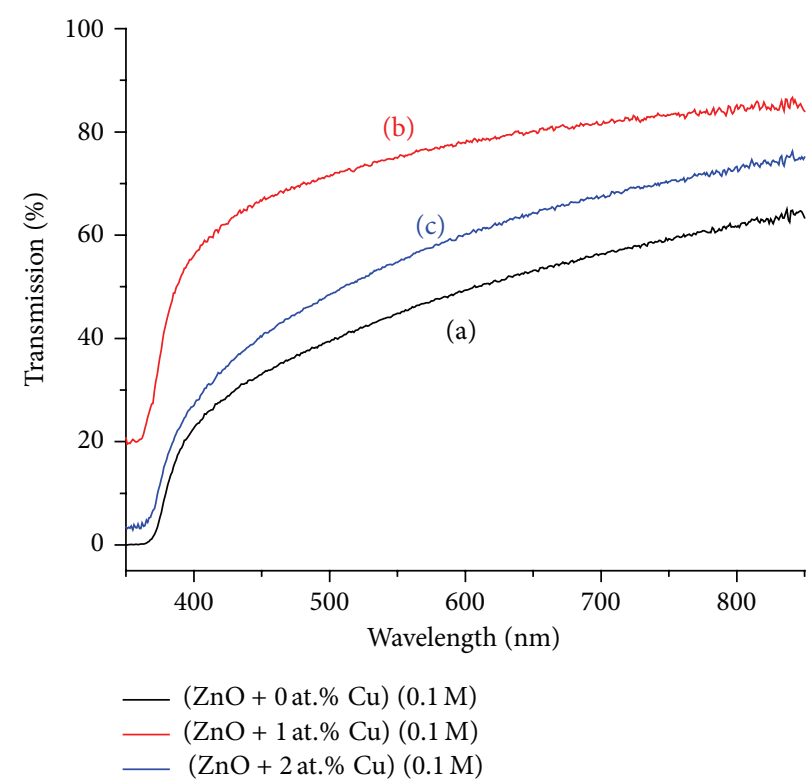

Figure 3: Transmission spectra of undoped and $\mathrm{Cu}$ doped $\mathrm{ZnO}$ thin films sample. Here (a), (b), and (c) correspond to samples Z1, Z1C1, and $\mathrm{Z1C2}$, respectively, prepared using precursor solution of molarity of $0.1 \mathrm{M}$.

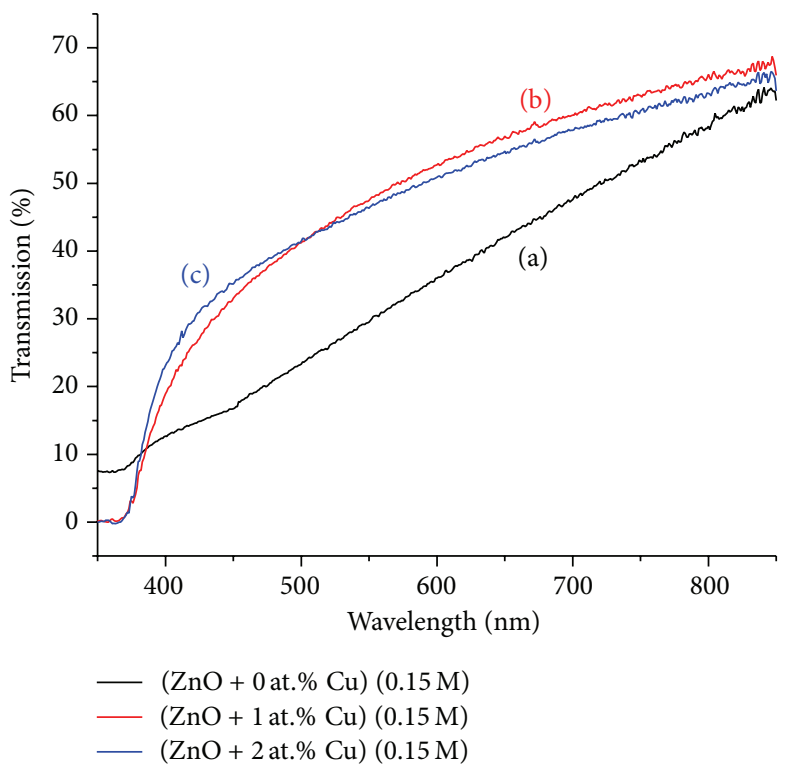

Figure 4: Transmission spectra of undoped and $\mathrm{Cu}$ doped $\mathrm{ZnO}$ thin films sample. Here (a), (b), and (c) correspond to samples Z2, Z2C1, and $\mathrm{Z} 2 \mathrm{C} 2$, respectively, prepared using precursor solution of molarity of $0.15 \mathrm{M}$.

Z1C2 increases gradually up to $87 \%$ over the range of 350 to $850 \mathrm{~nm}$, Figure 3. The maximum transmittance for samples $\mathrm{Z} 2, \mathrm{Z2C1}$, and $\mathrm{Z} 2 \mathrm{C} 2$ is nearly $69 \%$ at $847 \mathrm{~nm}$. Undoped film of lower molarity is more transparent at optical wavelengths, whereas around $800 \mathrm{~nm}$ both of the undoped films have similar transmittance. High transmittance indicates that the obtained films are of low impurities and have only few lattice defects [24]. Doped films are comparatively more transparent. In general, the transmittance is found to decrease with an increase in molarity of the precursor solution as expected. The decrease in transmittance may be due to free carrier absorption of photons [25].

The thickness of $0.1 \mathrm{M}$ samples $\mathrm{Z} 1, \mathrm{Z1C1}$, and $\mathrm{Z1C2}$ is 1080,1100 , and $1050 \mathrm{~nm}$, respectively. For $0.15 \mathrm{M}$ samples $\mathrm{Z} 2, \mathrm{Z} 2 \mathrm{C1}$, and $\mathrm{Z} 2 \mathrm{C} 2$, the thickness is 1120, 1090, and $1100 \mathrm{~nm}$, respectively. The optical band gap of the films determined by Tauc's plot is found to vary over a range of 3.18 to $3.28 \mathrm{eV}$, Table 2 . The variation in 


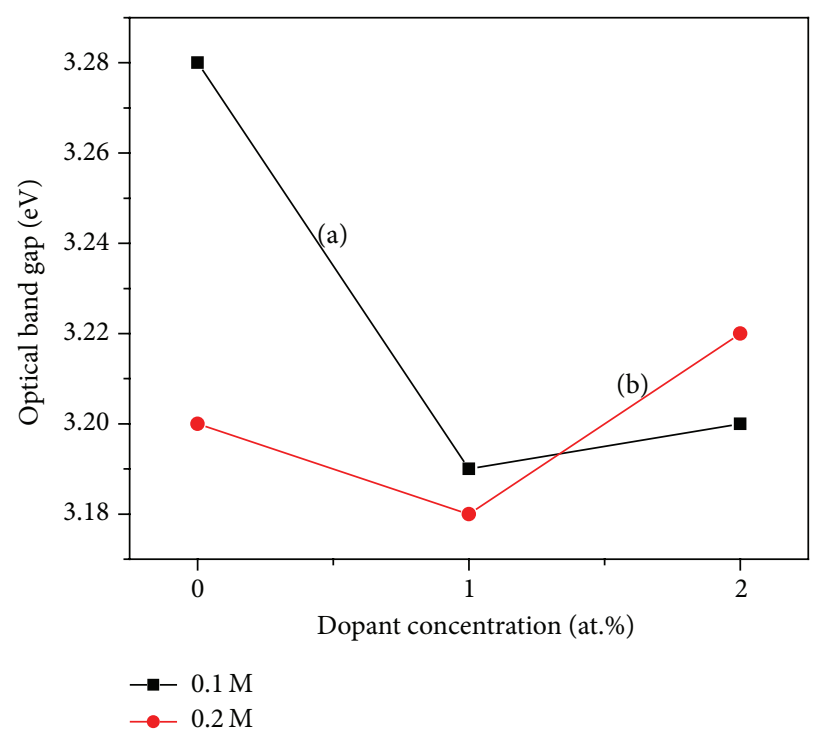

FIGURE 5: The variation in band gap (a) and (b) corresponds to the sample prepared using precursor solution of molarity of 0.1 and $0.15 \mathrm{M}$, respectively.

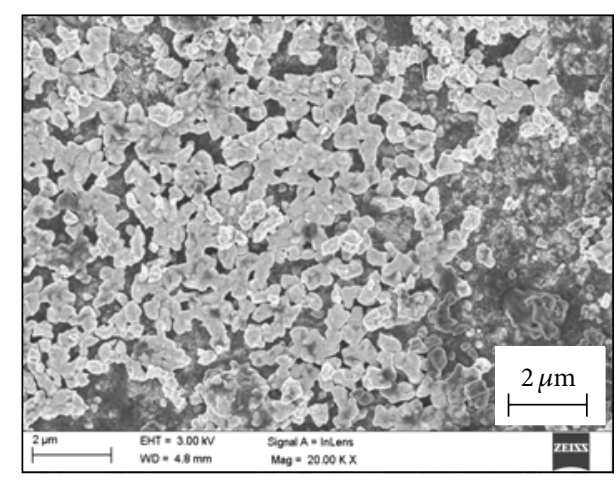

(a)

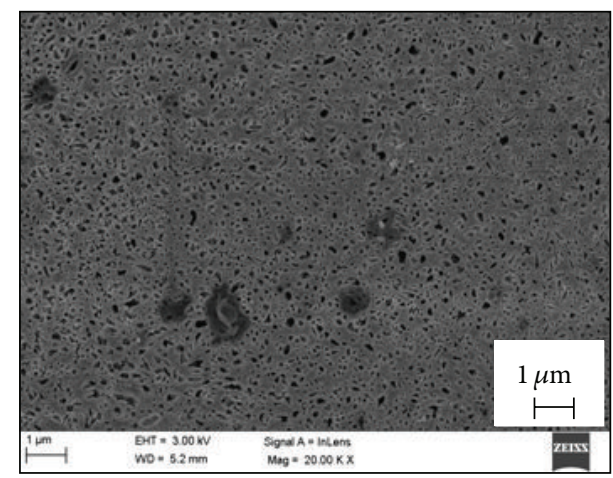

(b)

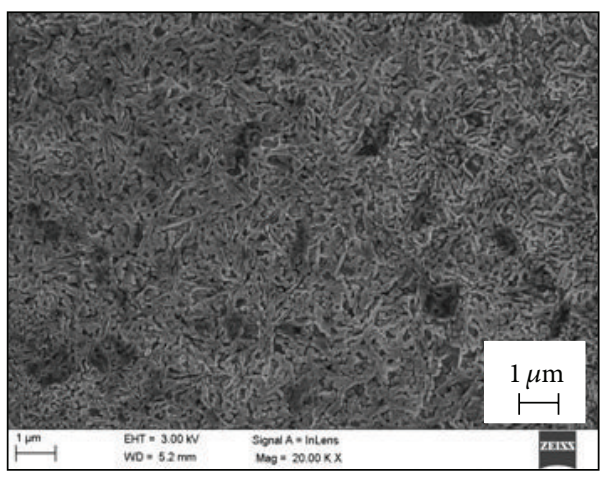

(c)

FIGURE 6: SEM of undoped and $\mathrm{Cu}$ doped $\mathrm{ZnO}$ thin films prepared using precursor solution of molarity of $0.1 \mathrm{M}$. Here (a), (b), and (c) correspond to samples $\mathrm{Z} 1, \mathrm{Z1C1}$, and $\mathrm{Z1C} 2$, respectively.

band gap due to doping and molar concentration is shown in Figure 5. For undoped $\mathrm{ZnO}$, the band gap decreases with increase in molarity of the precursor solution.
3.3. Surface Morphology. The scanning electron micrographs (SEM) for the three samples corresponding to $0.1 \mathrm{M}$ molarity are shown in Figure 6. Sample $\mathrm{Zl}$, that is, undoped $\mathrm{ZnO}$ of molarity $0.1 \mathrm{M}$, has flakes-like structures connected to each 


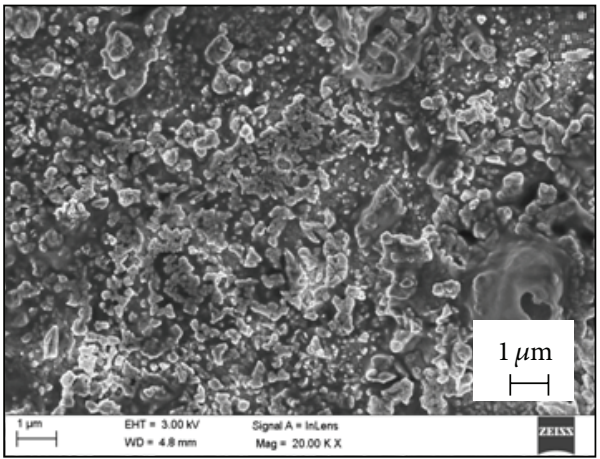

(a)

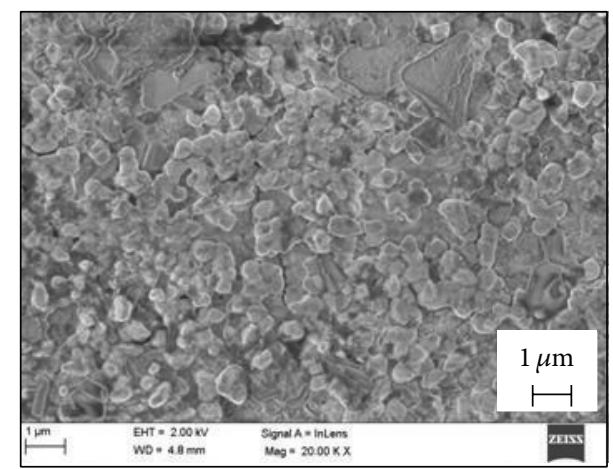

(b)

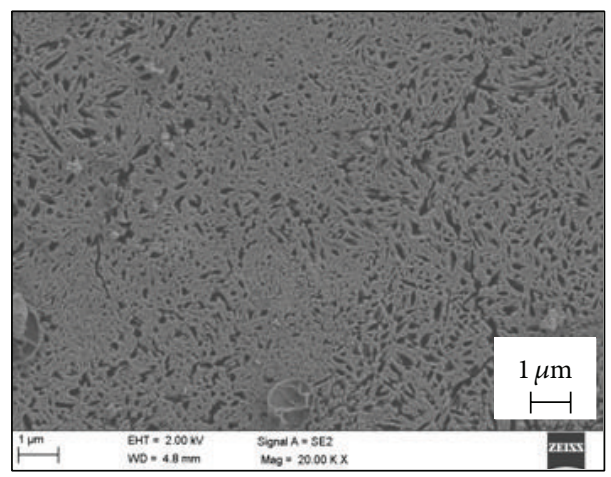

(c)

Figure 7: SEM of undoped and $\mathrm{Cu}$ doped $\mathrm{ZnO}$ thin films prepared using precursor solution of molarity of $0.15 \mathrm{M}$. Here (a), (b), and (c) correspond to samples $\mathrm{Z} 2, \mathrm{Z} 2 \mathrm{C} 1$, and $\mathrm{Z} 2 \mathrm{C} 2$, respectively.

TABLE 1: Crystallite size $\left(t_{D S}\right)$ and orientation parameter $(\gamma)$ of all the samples.

\begin{tabular}{lcccc}
\hline Samples & $\begin{array}{c}t_{D S}(\mathrm{~nm}) \\
(002)\end{array}$ & \multicolumn{3}{c}{ Orientation parameter $\left(\gamma_{(h k l)}\right)$} \\
& 21 & 0.141 & 0.772 & 0.156 \\
$\mathrm{Z} 1$ & 12 & 0.170 & 0.433 & 0.271 \\
$\mathrm{Z} 1 \mathrm{C} 1$ & 20 & 0.352 & 0.350 & 0.530 \\
$\mathrm{Z} 1 \mathrm{C} 2$ & 10 & 0.127 & 0.340 & 0.258 \\
$\mathrm{Z} 2$ & 15 & 0.147 & 0.374 & 0.253 \\
$\mathrm{Z} 2 \mathrm{C} 1$ & 15 & 0.145 & 0.375 & 0.253 \\
$\mathrm{Z} 2 \mathrm{C} 2$ & & & &
\end{tabular}

TABLE 2: Optical band gap of $\mathrm{Cu}$ doped $\mathrm{ZnO}$ thin films.

\begin{tabular}{lcc}
\hline Sample & Composition & Optical band gap $(\mathrm{eV})$ \\
\hline $\mathrm{Z} 1$ & $0.1 \mathrm{M} \mathrm{ZnO}$ & 3.28 \\
$\mathrm{Z} 1 \mathrm{C} 1$ & $0.1 \mathrm{M} \mathrm{ZnO}+1 \% \mathrm{CuCl}_{2}$ & 3.19 \\
$\mathrm{Z} 1 \mathrm{C} 2$ & $0.1 \mathrm{M} \mathrm{ZnO}+2 \% \mathrm{CuCl}_{2}$ & 3.20 \\
$\mathrm{Z} 2$ & $0.15 \mathrm{M} \mathrm{ZnO}$ & 3.20 \\
$\mathrm{Z} 2 \mathrm{C} 1$ & $0.15 \mathrm{M} \mathrm{ZnO}+1 \% \mathrm{CuCl}_{2}$ & 3.18 \\
$\mathrm{Z} 2 \mathrm{C} 2$ & $0.15 \mathrm{M} \mathrm{ZnO}+2 \% \mathrm{CuCl}_{2}$ & 3.22 \\
\hline
\end{tabular}

other to form bigger ones (Figure 6(a)). As the dopant $\mathrm{Cu}$ is introduced in 1 at.\% in $\mathrm{ZnO}$ (sample $\mathrm{Z1C1}$ ) film surface becomes netted with clear appearances of holes (Figure 6(b)) and for further increased doping of 2 at.\% the net making needle-like structures become dominant over the holes (Figure 6(c)).

Surface morphology of samples of molarity $0.15 \mathrm{M}$ are shown in Figure 7. Sample Z2 has random structures spread throughout the surface. For sample $\mathrm{Z} 2 \mathrm{C1}$, these random structures convert in irregular shaped grains. A network of small needle-like structures is seen for $\mathrm{Z} 2 \mathrm{C} 2$.

3.4. Gas Sensing. For a semiconductor gas sensor, where resistance varies with gas concentration, the sensitivity $S$ is defined as percent ratio of the resistance of the sensing film in air $\left(R_{\text {air }}\right)$ to the resistance in the presence of the gas $\left(R_{\mathrm{gas}}\right)$ [26] at a particular temperature; that is,

$$
S(\%)=\left(\frac{R_{\text {air }}}{R_{\text {gas }}}\right) \times 100 .
$$

For each concentration of analyte gas, which in the present case is $\mathrm{CO}_{2}$, the temperature of the films is varied from 200 to $450^{\circ} \mathrm{C}$ in steps of $50^{\circ} \mathrm{C}$ and observations are taken. Before introducing the gas, sensing film is allowed to stabilize to ensure fixed initial reading for gas sensing application [27].

Figures 8 and 9 show the effect of temperature on the sensitivity of undoped and copper doped $\mathrm{ZnO}$ thin films for four different carbon dioxide concentrations. 


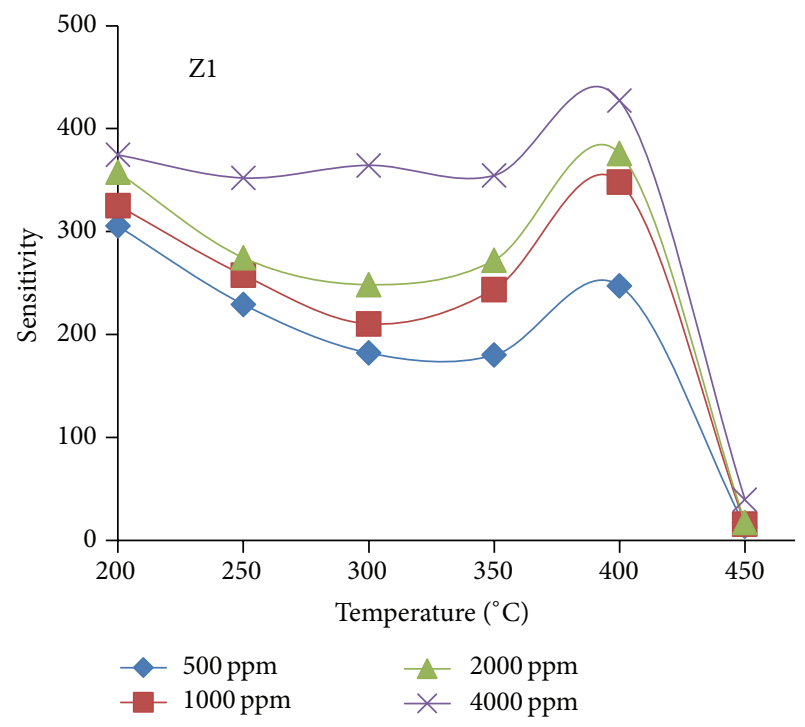

(a)

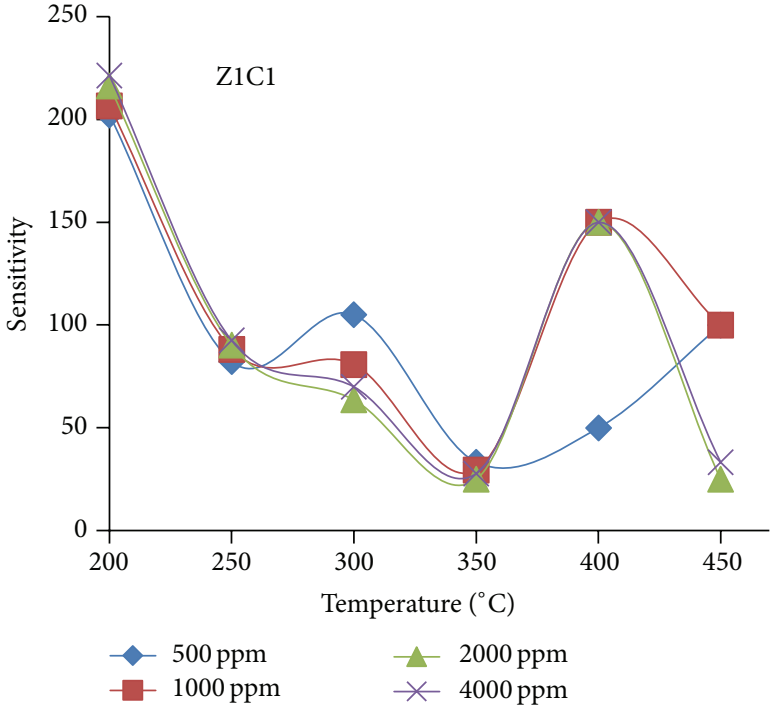

(b)

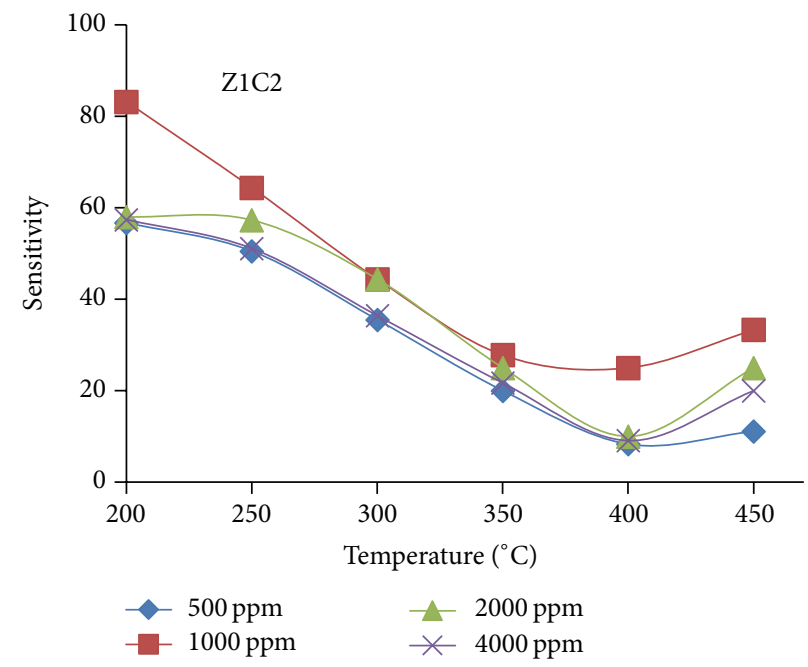

(c)

FIgURE 8: Variation of sensitivity of undoped and $\mathrm{Cu}$ doped $\mathrm{ZnO}$ thin film samples at various $\mathrm{CO}_{2}$ concentrations with temperature. Here (a), (b), and (c) correspond to samples Z1, Z1C1, and Z1C2, respectively, prepared using precursor solution of molarity of $0.1 \mathrm{M}$.

For sample $\mathrm{Zl}$, sensitivity is maximum at $400^{\circ} \mathrm{C}$ for all concentrations of $\mathrm{CO}_{2}$ and the sensitivity increases with increase in concentration of $\mathrm{CO}_{2}$. For sample $\mathrm{ZlCl}$, the sensitivity is again maximum at $400^{\circ} \mathrm{C}$ except for $500 \mathrm{ppm}$ concentration whereas for sample $\mathrm{Z1C} 2$ the sensitivity is minimum at $400^{\circ} \mathrm{C}$ and maximum at $200^{\circ} \mathrm{C}$. Such behavior can be attributed to the changing surface morphology of samples (Figure 8).

For sample Z2, maximum sensitivity occurs below $300^{\circ} \mathrm{C}$ whereas for sample $\mathrm{Z} 2 \mathrm{Cl}$ maxima occur at $300^{\circ} \mathrm{C}$. For sample $\mathrm{Z} 2 \mathrm{C} 2$, again the sensitivity is maximum at lower temperature. It is seen that presence of more and more dopant decreases the sensitivity of the films towards carbon dioxide.

The variation in sensitivity with temperature for 500 , 1000,2000 , and $4000 \mathrm{ppm}$ of $\mathrm{CO}_{2}$ concentration is shown in Figures 10(a), 10(b), 10(c) and 10(d) respectively.
The sensitivity has high value at $200^{\circ} \mathrm{C}$ for samples $\mathrm{ZlCl}$ and $\mathrm{Z1C} 2$ at all gas concentrations. However, sample Z1C2 has maximum sensitivity for $1000 \mathrm{ppm}$ at $200^{\circ} \mathrm{C}$. An increase in temperature decreases the sensitivity in both these samples whereas for samples $\mathrm{Z} 2 \mathrm{Cl}$ and $\mathrm{Z} 2 \mathrm{C} 2$ the sensitivity has low value at low operating temperature. Sample $\mathrm{Z} 2 \mathrm{C} 1$ has maximum sensitivity at $300^{\circ} \mathrm{C}$ for $500 \mathrm{ppm}$. Sample Z2C2 has maximum sensitivity at $250^{\circ} \mathrm{C}$ for $2000 \mathrm{ppm}$.

Band theory as applied to gas sensors has been the subject of intense study for a number of years $[28,29]$. The analyte carbon dioxide gas interacts with the surface of the metal oxide film (generally through surface adsorbed oxygen ions), which results in a change in charge carrier concentration [30] altering the conductivity (or resistivity) of the material. An ntype semiconductor is one where the majority charge carriers are electrons, and upon interaction with a reducing gas an 


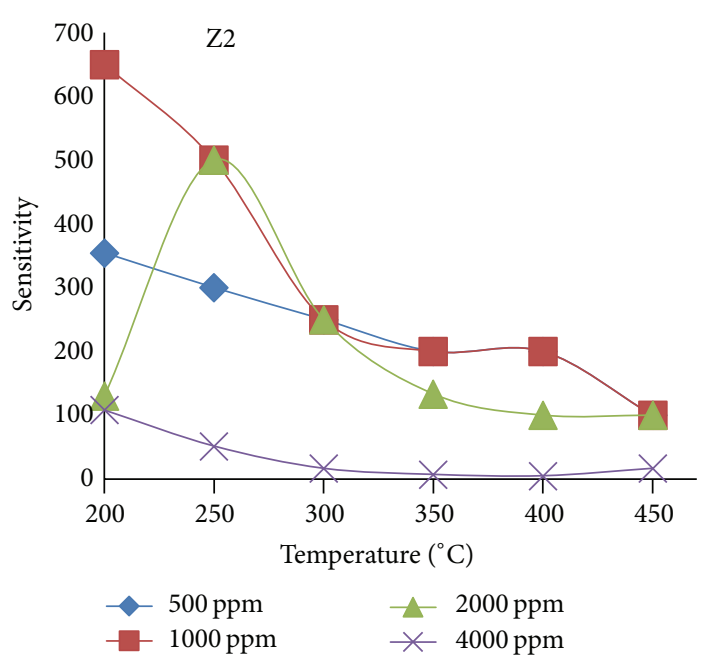

(a)

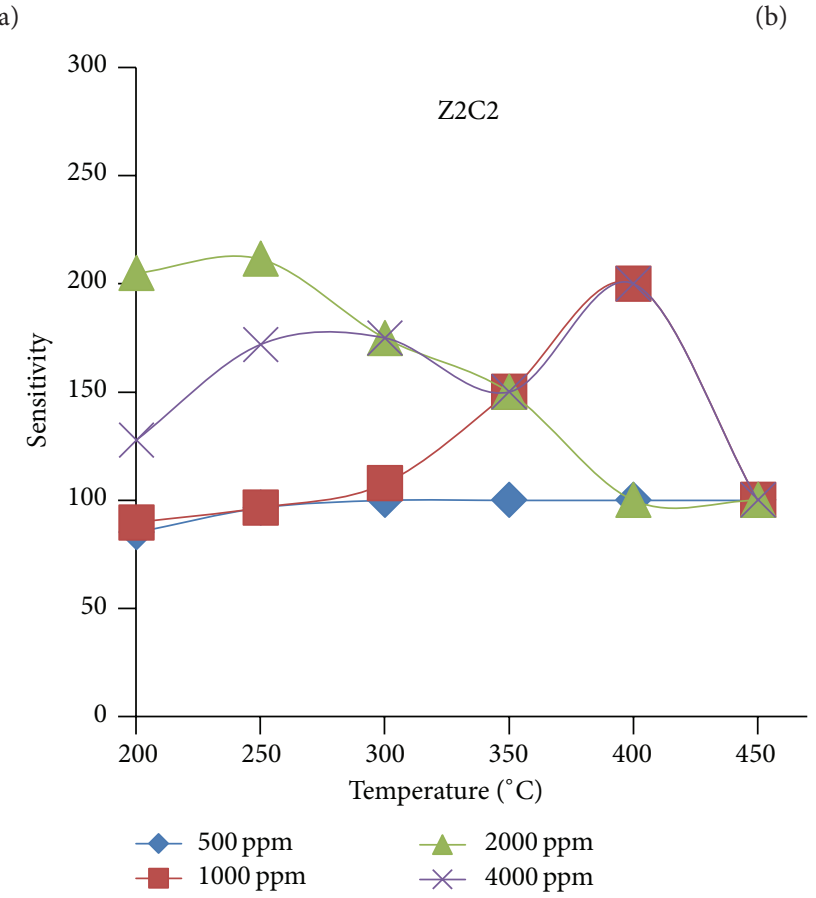

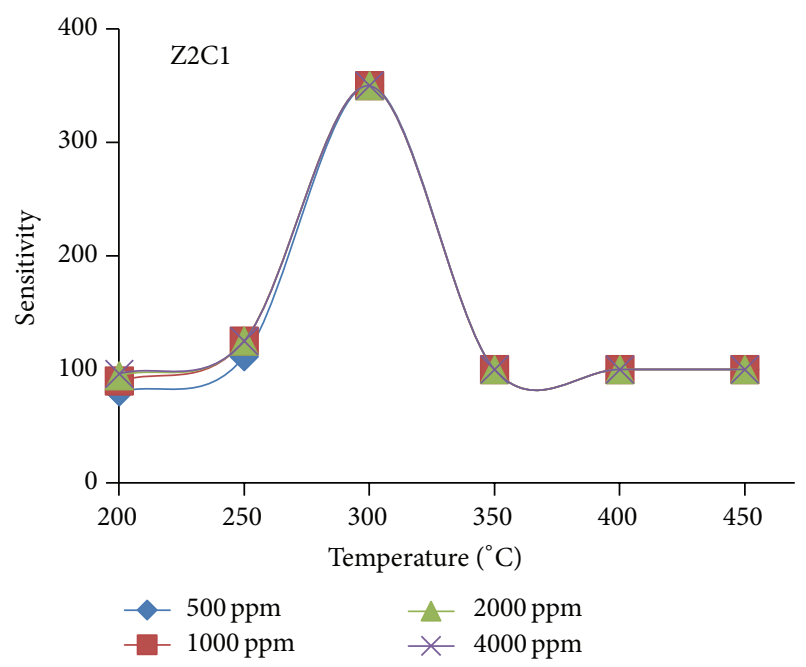

(b)

(c)

FIgURE 9: Variation of sensitivity of undoped and $\mathrm{Cu}$ doped $\mathrm{ZnO}$ thin film samples at various $\mathrm{CO}_{2}$ concentrations with temperature. Here (a), (b), and (c) correspond to samples $\mathrm{Z} 2, \mathrm{Z} 2 \mathrm{C}$, and $\mathrm{Z} 2 \mathrm{C} 2$, respectively, prepared using precursor solution of molarity $0.15 \mathrm{M}$.

increase in conductivity occurs. However, change in charge carrier concentration in the sample also depends upon the amount of the adsorbed gas which in turn depends on the surface morphology. Thus, the nature of the analyte gas and the surface morphology of the films both should be taken into account while comparing the resistance, $R_{\mathrm{gas}}$, of a sample in presence of varying concentration of the gas.

\section{Conclusions}

Nanocrystalline $\mathrm{Cu}$ doped $\mathrm{ZnO}$ films have been successfully deposited on glass substrates by spray pyrolysis and their structural and optical properties have been investigated.
The crystallite size decreases with increase in molarity of precursor solution whereas with doping the crystallite size increases in general. Doping increases the transmittance of the films whereas optical band gap first decreases and then increases as the dopant concentration is gradually increased for both molarities in reference. As the doping increases, the SEM shows formation of irregular shaped grains and then netted structure with holes followed by net making needle-like structures becoming dominant over the holes for both molarities. Response of these films for carbon dioxide has been studied. Undoped $\mathrm{ZnO}$ shows maximum sensitivity at $400^{\circ} \mathrm{C}$ for higher concentration of $\mathrm{CO}_{2}$. The sensitivity of $\mathrm{Cu}$ doped sample is 

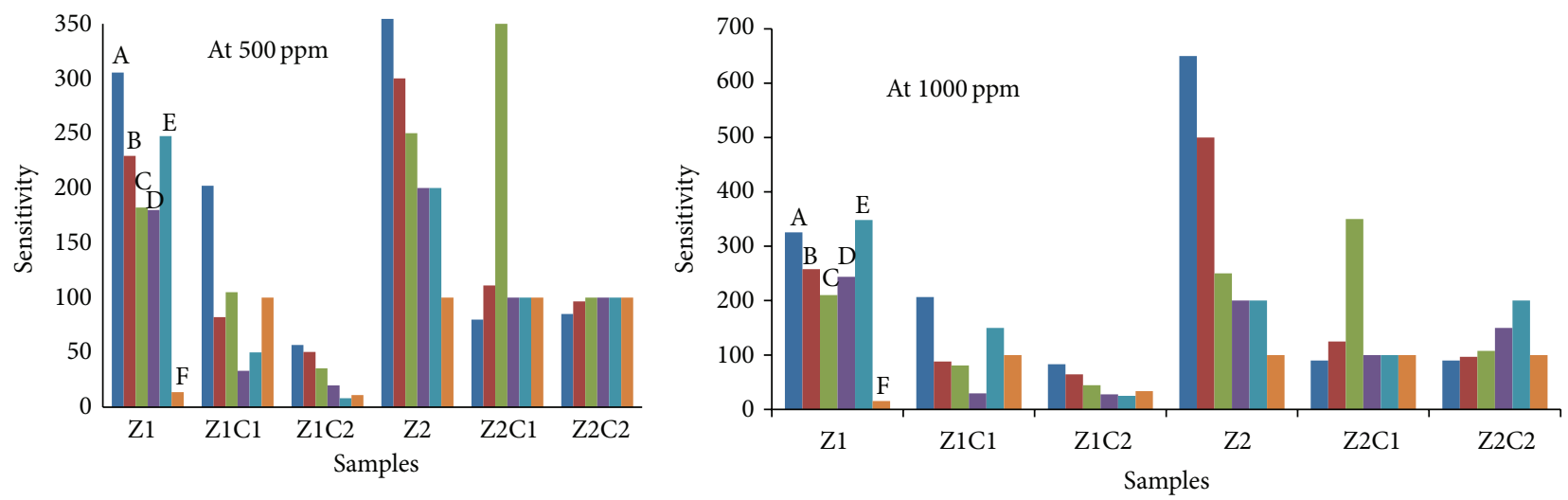
- (A) $200^{\circ} \mathrm{C}$
- (B) $250^{\circ} \mathrm{C}$
- (C) $300^{\circ} \mathrm{C}$
- (D) $350^{\circ} \mathrm{C}$
- (F) $450^{\circ} \mathrm{C}$

(a)

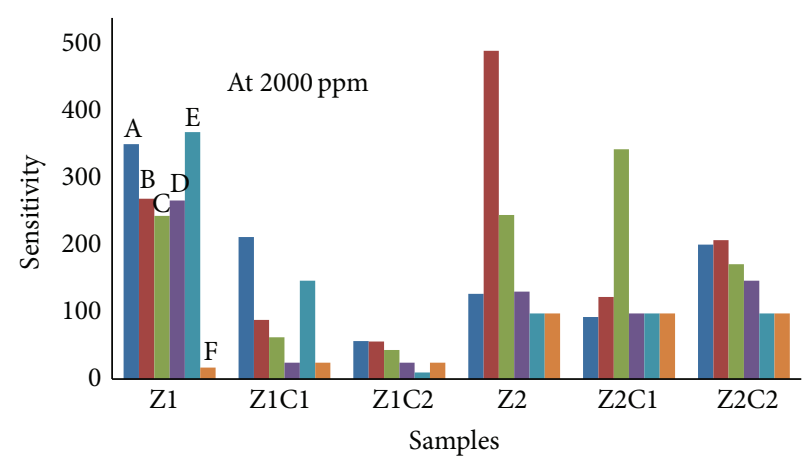

- (A) $200^{\circ} \mathrm{C}$

- (B) $250^{\circ} \mathrm{C}$

- (C) $300^{\circ} \mathrm{C}$

- (D) $350^{\circ} \mathrm{C}$

(E) $400^{\circ} \mathrm{C}$

(F) $450^{\circ} \mathrm{C}$

(c)

- (D) $350^{\circ} \mathrm{C}$

- (E) $400^{\circ} \mathrm{C}$

- (F) $450^{\circ} \mathrm{C}$

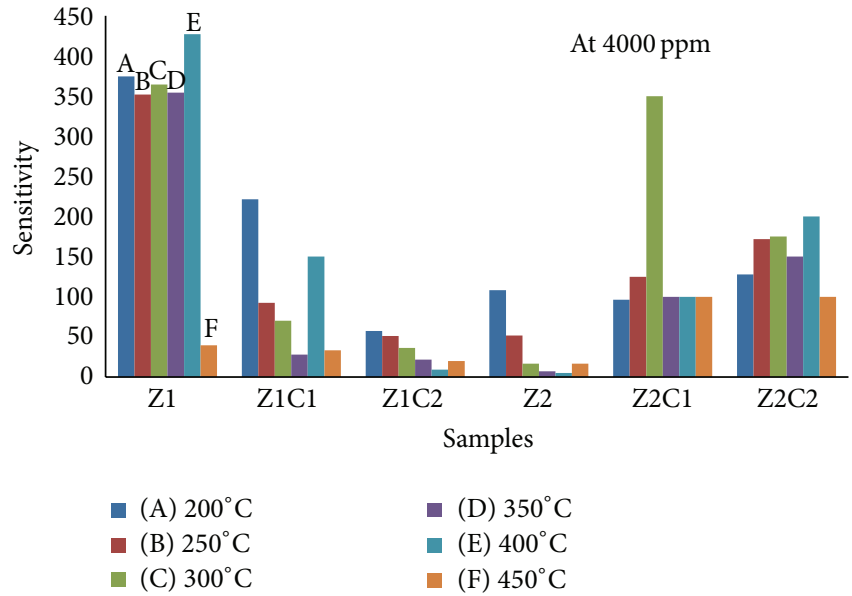

(d)

FIGURE 10: (a) Variation of sensitivity of undoped and $\mathrm{Cu}$ doped $\mathrm{ZnO}$ thin film samples at $500 \mathrm{ppm} \mathrm{CO}_{2}$ concentration with temperature. (b) Variation of sensitivity of undoped and $\mathrm{Cu}$ doped $\mathrm{ZnO}$ thin films sample at $1000 \mathrm{ppm} \mathrm{CO}_{2}$ concentrations with temperature. (c) Variation of sensitivity of undoped and $\mathrm{Cu}$ doped $\mathrm{ZnO}$ thin films sample at $2000 \mathrm{ppm} \mathrm{CO}_{2}$ concentrations with temperature. (d) Variation of sensitivity of undoped and $\mathrm{Cu}$ doped $\mathrm{ZnO}$ thin film samples at $4000 \mathrm{ppm} \mathrm{CO}_{2}$ concentration with temperature.

maximum at $200^{\circ} \mathrm{C}$ for all $\mathrm{CO}_{2}$ concentrations from 500 to 4000 ppm.

\section{Conflict of Interests}

The authors declare that there is no conflict of interests regarding the publication of this paper.

\section{References}

[1] A. K. Das, P. Misra, and L. M. Kukreja, "Effect of Si doping on electrical and optical properties of $\mathrm{ZnO}$ thin films grown by sequential pulsed laser deposition," Journal of Physics D: Applied Physics, vol. 42, no. 16, Article ID 165405, 2009.

[2] S. Y. Pung, C. S. Ong, K. Mohd Isha, and M. H. Othman, "Synthesis and characterization of $\mathrm{Cu}$-doped zno nanorods," Sains Malaysiana, vol. 43, no. 2, pp. 273-281, 2014.
[3] B. Allabergenov, O. Tursunkulov, A. I. Abidov, B. Choi, J. S. Wook, and S. Kim, "Microstructural analysis and optical characteristics of $\mathrm{Cu}$-doped $\mathrm{ZnO}$ thin films prepared by $\mathrm{DC}$ magnetron sputtering," Journal of Crystal Growth, vol. 401, pp. 573-576, 2014.

[4] Y.-Q. Bie, Z.-M. Liao, P.-W. Wang et al., "Single $\mathrm{ZnO}$ nanowire/p-type GaN heterojunctions for photovoltaic devices and UV light-emitting diodes," Advanced Materials, vol. 22, no. 38, pp. 4284-4287, 2010.

[5] P. S. Shewale, V. B. Patil, S. W. Shin, J. H. Kim, and M. D. Uplane, " $\mathrm{H}_{2} \mathrm{~S}$ gas sensing properties of nanocrystalline $\mathrm{Cu}$-doped $\mathrm{ZnO}$ thin films prepared by advanced spray pyrolysis," Sensors and Actuators B: Chemical, vol. 186, pp. 226-234, 2013.

[6] A. T. Marin, D. Muñoz-Rojas, D. C. Iza, T. Gershon, K. P. Musselman, and J. L. MacManus-Driscoll, "Novel atmospheric growth technique to improve both light absorption and charge collection in $\mathrm{ZnO} / \mathrm{Cu}_{2} \mathrm{O}$ thin film solar cells," Advanced Functional Materials, vol. 23, no. 27, pp. 3413-3419, 2013. 
[7] J.-H. Jeon, S.-Y. Jeong, C.-R. Cho et al., "Heteroepitaxial relation and optical properties of $\mathrm{Cu}$-doped $\mathrm{ZnO}$ films grown by using pulsed laser deposition," Journal of the Korean Physical Society, vol. 54, no. 2, pp. 858-862, 2009.

[8] M. Bedir, M. Öztas, A. N. Yazici, and E. V. Kafadar, "Characterization of undoped and $\mathrm{Cu}$-doped $\mathrm{ZnO}$ thin films deposited on glass substrates by spray pyrolysis," Chinese Physics Letters, vol. 23, no. 4, pp. 939-942, 2006.

[9] M. B. Rahmani, S. H. Keshmiri, M. Shafiei et al., "Transition from $\mathrm{n}$ - to p-type of spray pyrolysis deposited $\mathrm{Cu}$ doped $\mathrm{ZnO}$ thin films for $\mathrm{NO}_{2}$ sensing," Sensor Letters, vol. 7, no. 4, pp. 621628, 2009.

[10] S. Dixit, A. Srivastava, A. Srivastava, and R. K. Shukla, "Effect of toxic gases on humidity sensing property of nanocrystalline ZnO film," Journal of Applied Physics, vol. 102, no. 11, Article ID 113114, 2007.

[11] B. Allabergenov, S.-H. Chung, S. M. Jeong, S. Kim, and B. Choi, "Enhanced blue photoluminescence realized by copper diffusion doping of $\mathrm{ZnO}$ thin films," Optical Materials Express, vol. 3, no. 10, pp. 1733-1741, 2013.

[12] K. P. Misra, R. K. Shukla, A. Srivastava, and A. Srivastava, "Blueshift in optical band gap in nanocrystalline $\mathrm{Zn}_{1-\mathrm{x}} \mathrm{Ca}_{\mathrm{x}} \mathrm{O}$ films deposited by sol-gel method," Applied Physics Letters, vol. 95, no. 3, Article ID 031901, 2009.

[13] C.-H. Hsu, L.-C. Chen, and X. Zhang, "Effect of the CU source on optical properties of CuZnO films deposited by ultrasonic spraying," Materials, vol. 7, no. 2, pp. 1261-1270, 2014.

[14] C. Wang, Z. Chen, Y. He, L. Li, and D. Zhang, "Structure, morphology and properties of Fe-doped $\mathrm{ZnO}$ films prepared by facing-target magnetron sputtering system," Applied Surface Science, vol. 255, no. 15, pp. 6881-6887, 2009.

[15] V. S. Kalyamwar, F. C. Raghuwanshi, N. L. Jadhao, and A. J. Gadewar, "Zinc oxide nanostructure thick films as $\mathrm{H}_{2} \mathrm{~S}$ gas sensors at room temperature," Journal of Sensor Technology, vol. 3, no. 3, pp. 31-35, 2013.

[16] F. K. Shan, B. I. Kim, G. X. Liu et al., "Blue shift of near band edge emission in $\mathrm{Mg}$ doped $\mathrm{ZnO}$ thin films and aging," Journal of Applied Physics, vol. 95, no. 9, pp. 4772-4776, 2004.

[17] D. Mishra, A. Srivastava, A. Srivastava, and R. K. Shukla, "Bead structured nanocrystalline $\mathrm{ZnO}$ thin films: synthesis and LPG sensing properties," Applied Surface Science, vol. 255, no. 5, pp. 2947-2950, 2008.

[18] G. Shanmuganathan and I. B. Shameem Banu, "Influence of codoping on the optical properties of $\mathrm{ZnO}$ thin films synthesized on glass substrate by chemical bath deposition method," Advances in Condensed Matter Physics, vol. 2014, Article ID 761960, 9 pages, 2014.

[19] P. S. Patil, "Versatility of chemical spray pyrolysis technique," Materials Chemistry and Physics, vol. 59, no. 3, pp. 185-198, 1999.

[20] P. Samarasekara, N. U. S. Yapa, N. T. R. N. Kumara, and M. V. K. Perera, " $\mathrm{CO}_{2}$ gas sensitivity of sputtered zinc oxide thin films," Bulletin of Materials Science, vol. 30, no. 2, pp. 113-116, 2007.

[21] T. M. Hammad, J. K. Salem, R. G. Harrison, R. Hempelmann, and N. K. Hejazy, "Optical and magnetic properties of Cudoped ZnO nanoparticles," Journal of Materials Science: Materials in Electronics, vol. 24, no. 8, pp. 2846-2852, 2013.

[22] G.-H. Zhang, X.-Y. Deng, H. Xue, and G. Xiang, "Engineering of electronic and optical properties of $\mathrm{ZnO}$ thin films via $\mathrm{Cu}$ doping," Chinese Physics B, vol. 22, no. 4, Article ID 047803, 2013.
[23] A. Srivastava, N. Kumar, K. P. Misra, and S. Khare, "Bluelight luminescence enhancement and increased band gap from calcium-doped zinc oxide nanoparticle films," Materials Science in Semiconductor Processing, vol. 26, no. 1, pp. 259-266, 2014.

[24] A. Ashour, M. A. Kaid, N. Z. El-Sayed, and A. A. Ibrahim, "Physical properties of $\mathrm{ZnO}$ thin films deposited by spray pyrolysis technique," Applied Surface Science, vol. 252, no. 22, pp. 7844-7848, 2006.

[25] J. P. Upadhyay, S. R. Vishwakarma, and H. C. Prasad, "Studies of electrical and optical properties of $\mathrm{SnO}_{2}: \mathrm{P}$ films," Thin Solid Films, vol. 169, no. 2, pp. 195-204, 1989.

[26] R. S. Khadayate, R. B. Waghulde, M. G. Wankhede, J. V. Sali, and P. P. Patil, "Ethanol vapour sensing properties of screen printed $\mathrm{WO}_{3}$ thick films," Bulletin of Materials Science, vol. 30, no. 2, pp. 129-133, 2007.

[27] P. Mitra, A. P. Chatterjee, and H. S. Maiti, " $\mathrm{ZnO}$ thin film sensor," Materials Letters, vol. 35, no. 1-2, pp. 33-38, 1998.

[28] N. Yamazoe, J. Fuchigami, M. O. Kishikawa, and T. Seiyama, "Interactions of tin oxide surface with $\mathrm{O}_{2}, \mathrm{H}_{2} \mathrm{O}$ and $\mathrm{H}_{2}$," Surface Science, vol. 86, pp. 335-344, 1979.

[29] N. Barsan, M. Schweizer-Berberich, and W. Göpel, "Fundamental and practical aspects in the design of nanoscaled $\mathrm{SnO} 2$ gas sensors: a status report," Fresenius' Journal of Analytical Chemistry, vol. 365, no. 4, pp. 287-304, 1999.

[30] N. Bârsan and U. Weimar, "Understanding the fundamental principles of metal oxide based gas sensors; the example of $\mathrm{CO}$ sensing with $\mathrm{SnO}_{2}$ sensors in the presence of humidity," Journal of Physics: Condensed Matter, vol. 15, no. 20, pp. R813-R839, 2003. 

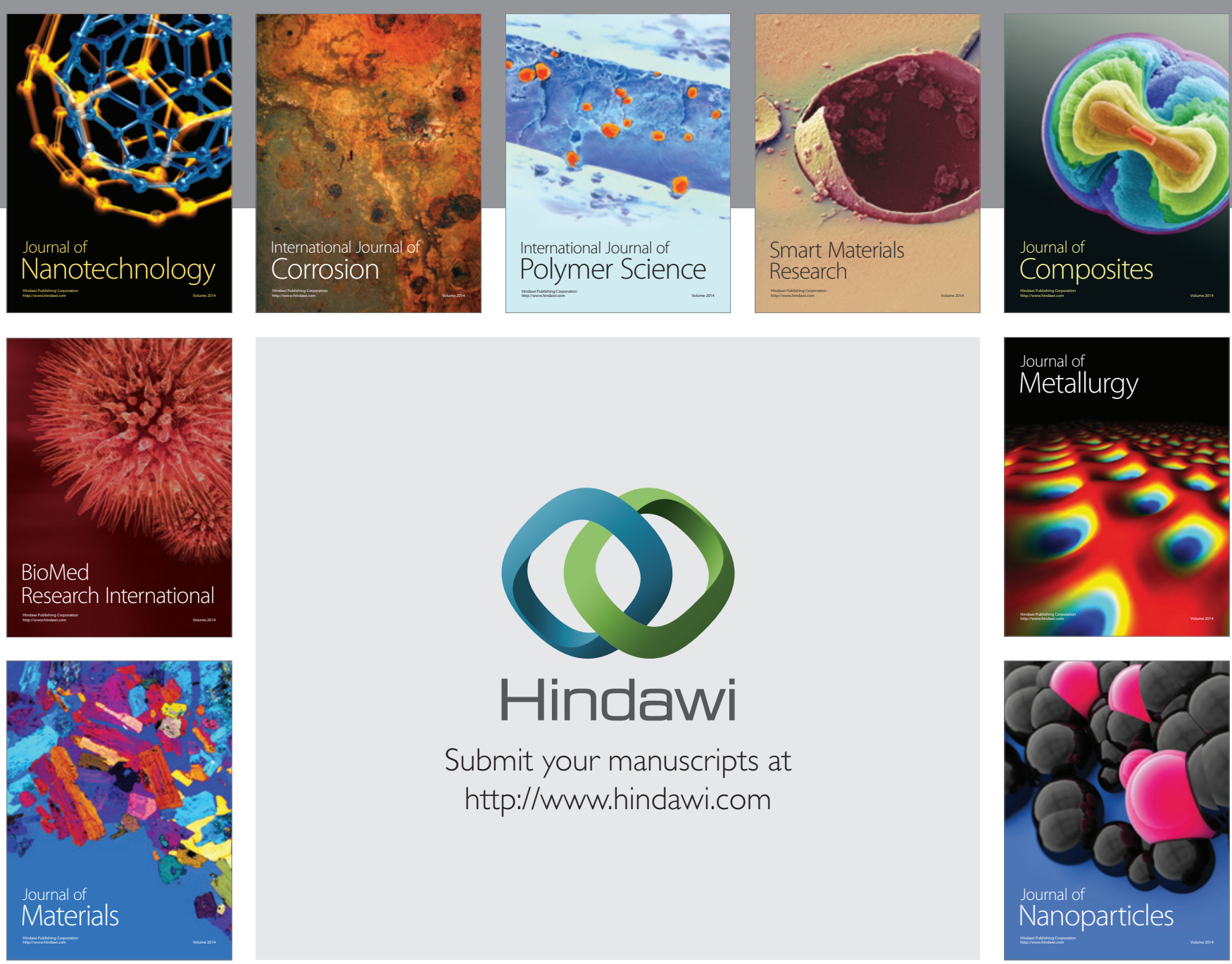

Submit your manuscripts at http://www.hindawi.com
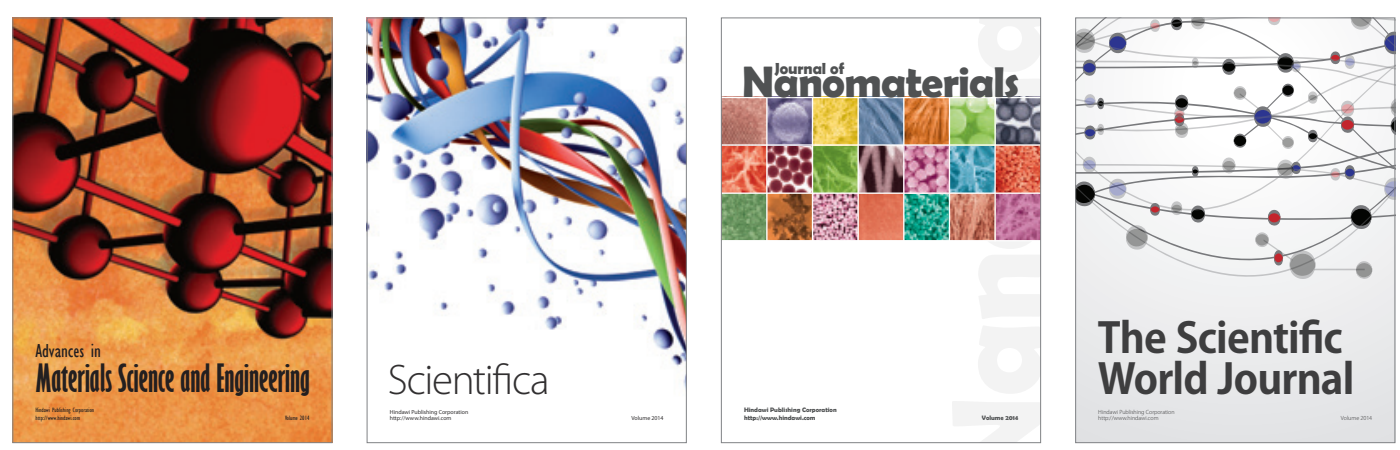

\section{The Scientific World Journal}
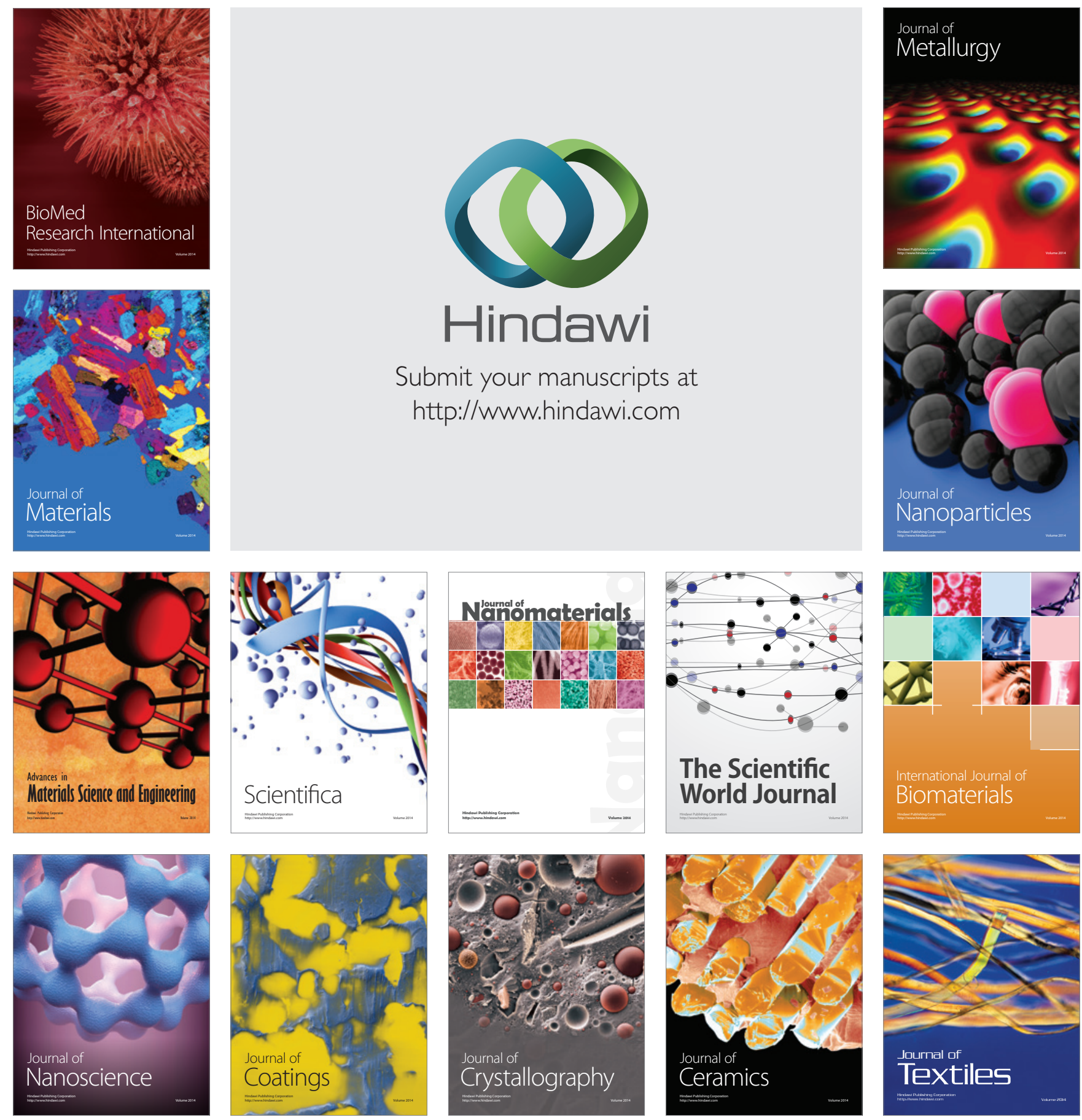